\begin{tabular}{lcccr} 
T H E & A R C H I V E & O F & M E C H A N I C A L & E N G I N E E R I N G \\
\hline VOL. LVII & 2010 & Number 1
\end{tabular}

Key words: unsteady compression, serial flow radial turbine

\title{
HYBRID WAVE ENGINE CONCEPT AND NUMERICAL SIMULATION OF ENGINE OPERATION
}

\begin{abstract}
Recent investigations of micro engines have documented the problem of low efficiency of steady compression devices [2]. As a solution, the application of unsteady processes has been proposed [1, 6, 17-20]. Closer investigations have shown the applicability of pure unsteady devices for gas compression, but it is also shown that they are practically not applicable for torque generation [21]. A new concept of the wave engine has to be developed.

This paper presents such a new concept and numerical investigation of the hybrid wave engine. A hybrid wave engine combines in a single machine components realizing unsteady compression, steady expansion, and mixed unsteady and steady scavenging due to the centrifugal force action. MEMS technology requires or prefers a flat geometry. Therefore, the use of a radial type of wave compression device for air compression is proposed. A numerical, two-dimensional complete model of this device was built, and several numerical simulations of engine operations were performed. The numerical model includes the simplified model of the combustion chamber closing the flow loop between the high-pressure compressed air port and the high-pressure hot exhaust gas port. The model represents the complete flow scheme of the hybrid wave engine. A special type of turbine in radial configuration with serial flow layout is used for torque generation.
\end{abstract}

\section{Introduction}

Many groups of researchers have focused their attention on the design of micro turbine engines in recent years $[2,4,6-8,16]$. The recent trend towards miniaturization of thermal engines to the centimeter and millimeter scale shows, on the one hand, a high power density of such devices and, on the other hand, a reduction of efficiency due to the downsizing effect [23,

* Warsaw University of Technology Institute of Aeronautics and Applied Mechanics ul. Nowowiejska 24,00-665 Warsaw, Poland; E-mail: jpie@meil.pw.edu.pl

** ETH Zurich, Dept. of Mechanical and Process Engineering, 8092 Zurich, Switzerland; E-mail:dyntar@imrt.mavt.ethz.ch 
25]. Efforts directed to the miniaturization of classic types of turbine engines resulted in a series of not very successful solutions [2]. The application of a non-conventional wave engine construction seems to be interesting.

In the long history of wave machine development $[5,10,12,16]$, two projects have concentrated on the wave engine. The first one was the Pearson wave engine [14], the second the Weber wave engine project [26].

The wave engine developed by Pearson was based on an axial wave rotor with oblique channels, with single-step compression and double-step decompression. The engine could operate in a relatively wide range of rotational speeds, which suggests that the principle of operation was only partially based on the typical unsteady flow principle.

The wave engine described by Weber was rather a topping unit for the turbo engine than a true wave engine. An additional wave rotor has realized the second step of compression of a classical turbo engine. Characteristic for that engine was the two-level decompression scheme.

Axial wave rotors driven by the inclined configuration of ports delivering fluid to the rotor have been known for a long time. Such solutions were tested in the construction of a free-running Comprex wave charger [12]. Also wave cooling devices made by Power Jets [10] was self-driven by using the highpressure inlet to give the entering flow an incidence angle of approximately $10 \mathrm{deg}$ to the cell walls at the operating speed.

Numerous theoretical and numerical investigations of pure wave engines have been documented by many authors [17-22]. The construction of a wave engine based only on the unsteady process utilizes the advantages of the unsteady compression. However, the same phenomena in the decompression part of the process decreases the ability to generate torque [21]. Thus, a new hybrid engine concept was developed, as presented in this paper.

\section{Hybrid wave engine idea}

Any turbo engine cycle contains the basic thermodynamic processes: compression, heat addition at constant pressure, and finally expansion.

Fig. 1 depicts the temperature-entropy diagram for the wave engine compared with the conventional turbo engine. The compression process (1-2) can be realized in a steady-state way by an axial or a radial compressor or in an unsteady way by a wave machine. Similarly, decompression (3-4 or 3'-4') can be realized in a steady way in an axial or a radial turbine or in an unsteady way by a wave machine. Maximal temperature of the thermodynamic cycle is determined by the turbine material. Wave rotor is self-cooled and its mean temperature is lower than the gas temperature. 


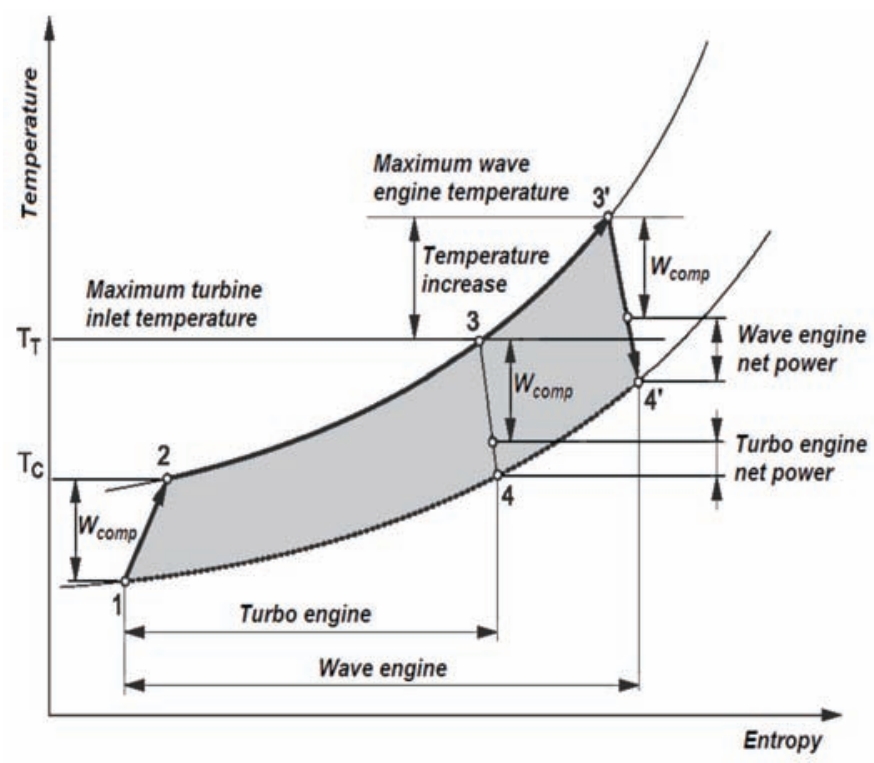

Fig. 1. T-s diagram for the wave engine compared with the conventional turbo engine

Due to that, for the same rotor and turbine material, wave rotor maximal cycle temperature can be higher. The potential advantages of the wave engine in the form of the increased maximum temperature and increased net power are evident.
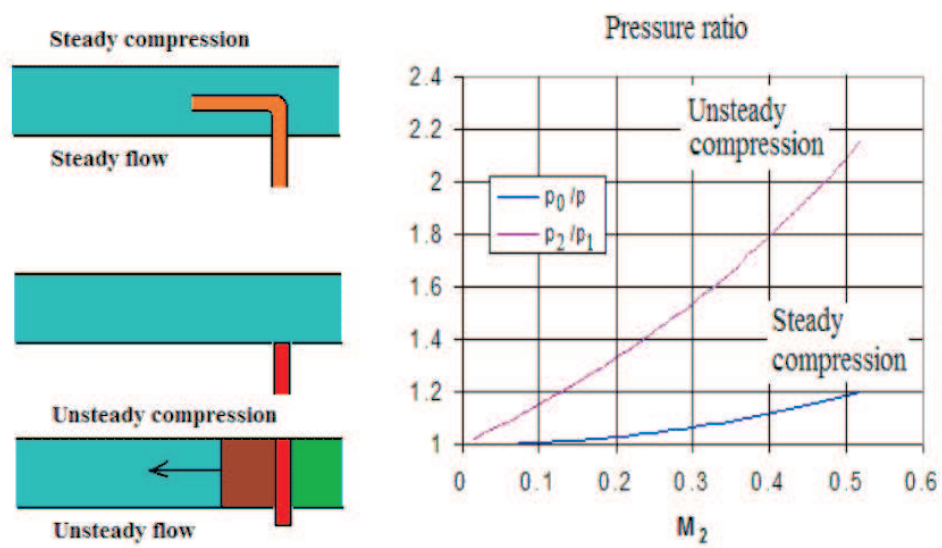

Fig. 2. Pressure ratios possible by unsteady and steady compression processes

The pressure ratio realizable by the use of initially the same flow velocity (Mach number) in steady and unsteady compression processes is depicted in Fig. 2. Generally, unsteady compression generates higher compression ratios, 
while unsteady processes are characterized by very short times of duration [24].

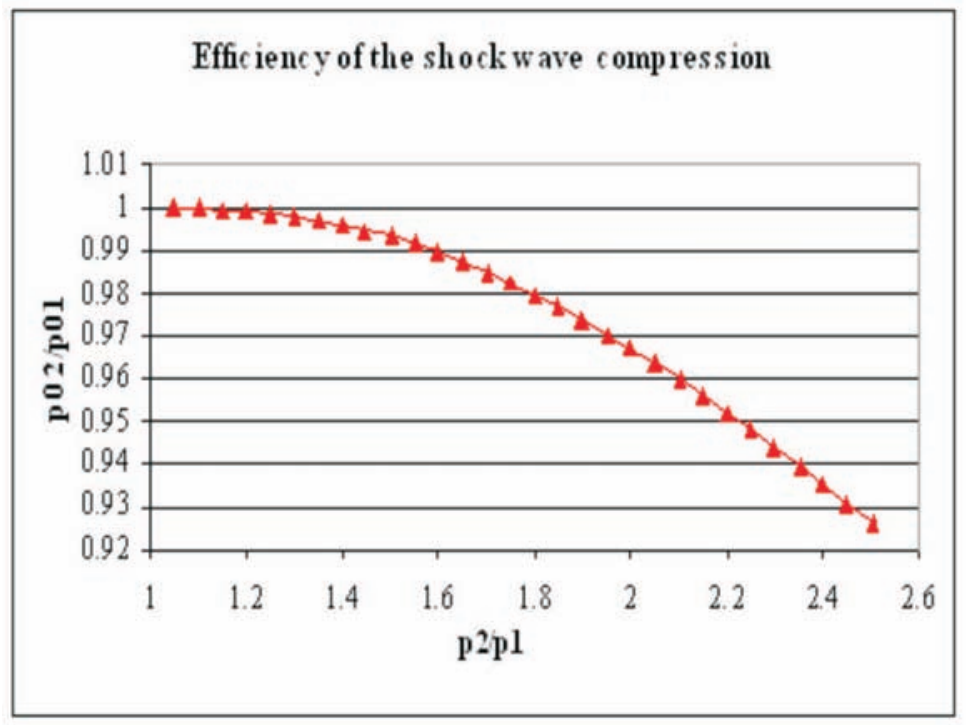

Fig. 3. Efficiency of the shock wave compression

As presented in Fig. 3, the efficiency of the compression process (ratio of the stagnation pressure on both sides of the shock), realized by the shock wave for a rather wide range of compression ratio, seems to be relatively high.

The state diagram in Fig. 4 visualizes the relation between pressure and velocity variations for the unsteady and steady compression and decompression. Thus it appears that the steady compression (1-2') yields a lower pressure increase than unsteady compression (1-2). However, the unsteady expansion from state 2 to state 1' generates a lower velocity increase than the steady process (2-3 in the upper graph).

Since the unsteady compression yields a higher pressure increase than the steady one, and the steady decompression yields a higher velocity increase than the unsteady process, it seems reasonable to use the unsteady compression to obtain a higher compression ratio and a steady decompression to realize the higher velocity values effectively exchanged into mechanical power by the conventional turbine.

Comparing the steady and unsteady compression and decompression processes, we can derive the following general conclusions. The optimal engine solution should be based on the unsteady compression and the steady decompression processes. Technically, it can be realised by the wave gas 

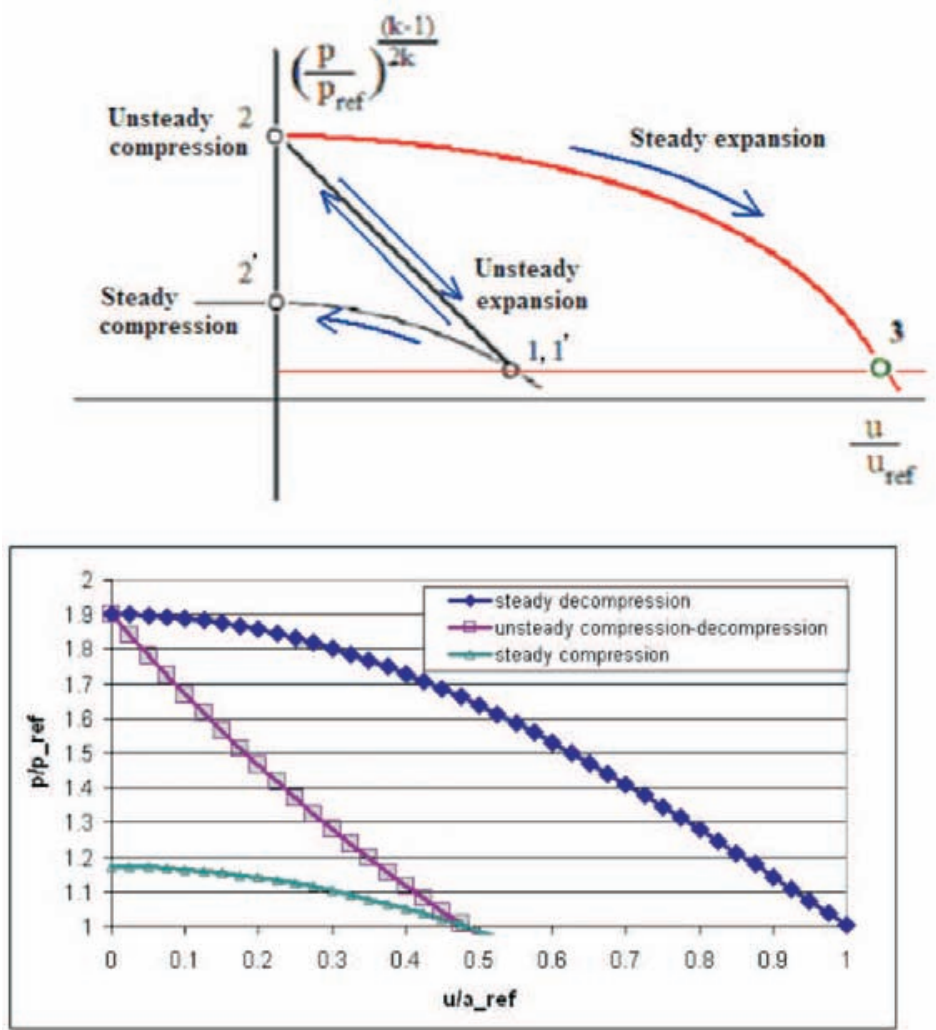

Fig. 4. The state diagram presenting a comparison of the steady and unsteady compression-decompression processes (qualitative and quantitative scheme)

generator and turbine torque generator. This paper presents such a general scheme of the hybrid engine. Unsteady processes are realized in a wave gas generator. Basic components of the axial type wave machines are presented in Fig. 5 in an extended view. Typically, the wave gas generator consists of a set of parallel channels (cells) combined in a rotor and playing a role of the compression-expansion chambers moving with constant velocity between steady walls containing ports through which the chambers are filled or emptied by air. Fig. 6 shows the wave pattern inside this component of hybrid wave engine together with the corresponding state plane. By setting the proper position and dimensions of the ports, it is possible to synchronise the unsteady flows in chambers to realize the compression of the fresh air by the expanding hot air heated in the combustion chamber. Such an ideally synchronised process is presented in Fig. 6.

The first wave compresses the fresh air from the state 0 to the state 1 , and after reflection and further compression to the state 2 . The compressed air with the pressure and velocity represented by state 2 is then delivered to 
the combustion chamber. However, the wave is reflecting again compressing the gas to the state 3 and then to the state 4 . The hot air pressure is stabilized by the gas pocket (point 5) to the level represented by point 6 .

Because the maximum reachable velocity after the steady decompression from state 7 is higher than the velocity reachable after the unsteady expansion (see Fig. 4 ), a part of the hot gas will be delivered to a turbine unit (highpressure exhaust). The remaining gas expands then to the outlet pressure (low pressure exhaust).

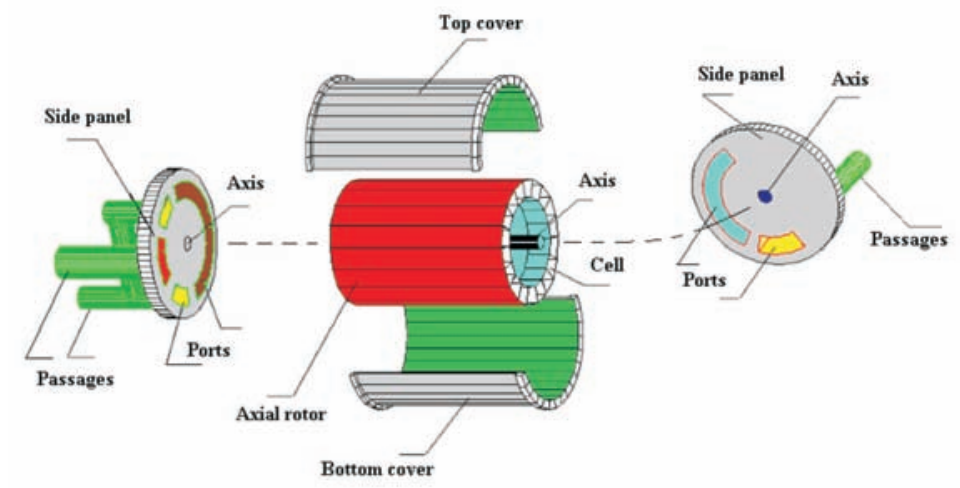

Fig. 5. Expanded view of the axial type wave machine components

Finally, after a series of reflections through the states 8 to 14 , exhaust gas in the rotor cells is replaced by fresh air. Velocities 9 to 14 are low and to fully reject the exhaust gas a longer time (many wave reflections) is required. Additional line passing states 1 to 13 indicate the position of temperature discontinuity ( hot-cold gas contact surface).

The principle of operation of a classic wave rotor comprises the following cycles:

1) high-pressure compression-decompression process used for compression of the fresh air,

2) unsteady decompression inducing the scavenging process.

The main problem in technical realization of a classical axial rotor wave engine is the scavenging process (phases 9-13 in Fig. 6). While the compression process in such a machine is not offering any great problems, the process of decompression is causing difficulties because it is very sensitive to the variations of exhaust pressure. Although the compression and decompression waves are very fast, the mass exchange (outflow of exhaust gases and inflow of fresh air) inside the rotor cells is very slow. Unfortunately, typically a good scavenging of the cells on the one hand, leads to the increased recirculation of exhaust gas, on the other hand. Such recirculation 

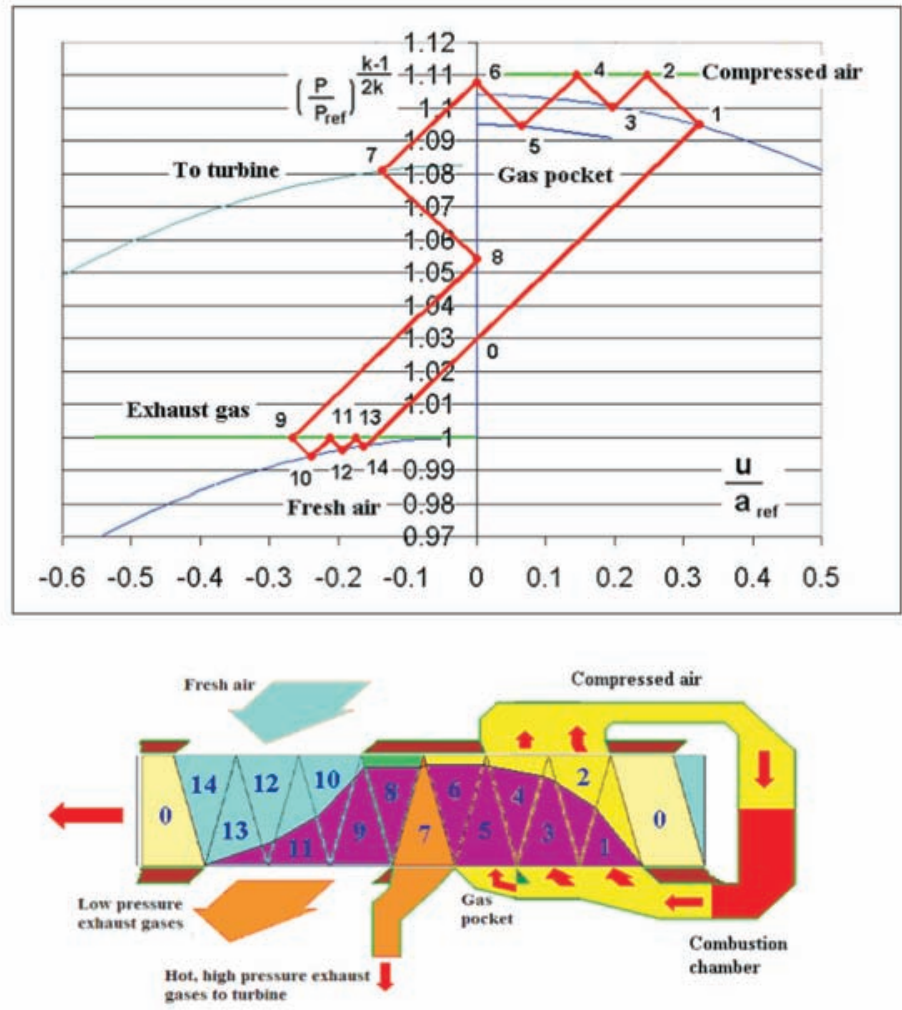

Fig. 6. Wave pattern and corresponding state plane in the wave gas generator, which is a part of the hybrid wave engine

causes strong overheating of the wave rotor walls. Therefore, the practical realization of the axial wave engine is rather difficult.

Simple analysis shows that the unsteady process, (see Fig. 4) generating high pressure changes and concurrent small velocity changes, is advantageous for compression. However, the steady process, generating higher velocities, is more suitable for decompression. For this reason, the wave engine proposed in this paper combines the advantages of unsteady compression and steady decompression. Therefore, we call this new device the hybrid wave engine.

In the radial wave rotor configuration [3, 6-8, 13, 15-22] the scavenging process is additionally supported by centrifugal forces, which improves the mass exchange into the rotor cells. Two-dimensional simulations of the hybrid wave engine confirmed the expected advantages of the proposed engine configuration.

In contrast to a classic axial rotor configuration, the proposed radial hybrid rotor configuration has very low exhaust gas recirculation, with the effect that the wave rotor's natural self-cooling feature is preserved. 


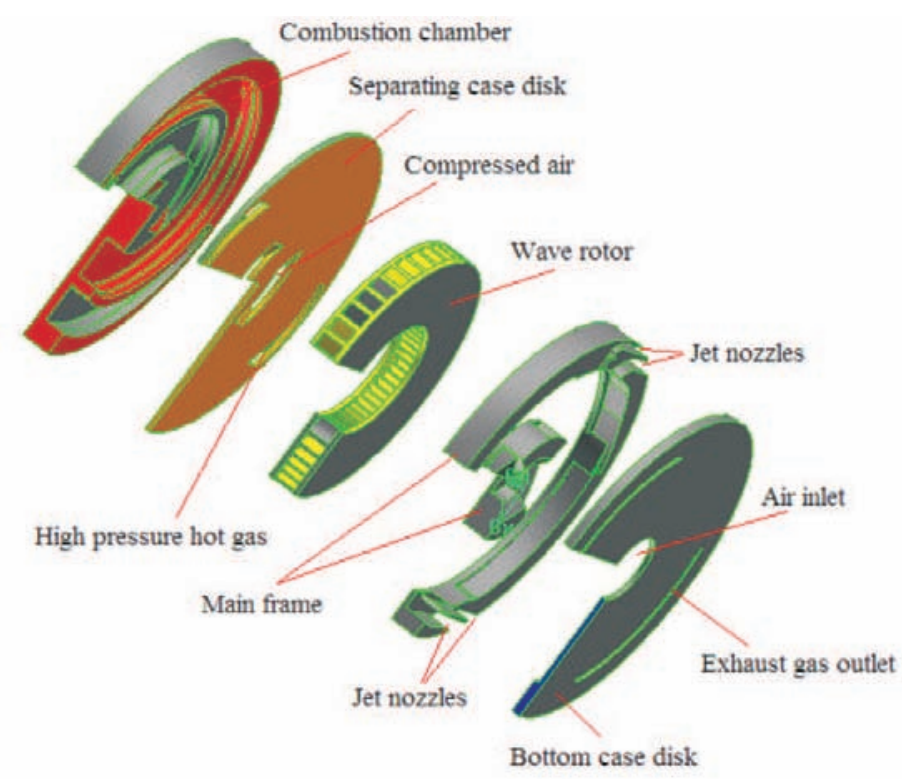

Fig. 7. Extended view of the possible jet wave engine realization in MEMS technology

The proposed radial hybrid wave engine configuration is also suitable for further miniaturization of the device. The radial wave rotor forms a thin disk with radial compression-decompression channels (cells). Due to its radial configuration, the disk has a greater diameter than the axial rotor, however, it is flat and thin. Therefore, for the production of the radial device, silicon wafer technology can be used. In Fig. 7 an extended view of the possible jet wave engine realized in MEMS technology is presented.

Wave rotor is located in main frame and closed by bottom case disk and separating case disk. It is a first layer of the stack. The second layer is formed by the combustion chamber. Gas flow between stack layers is possible by passages prepared in separating case disk. In the realization shown in Fig. 7, the wave disk is used as a gas generator and hot gas is expanded in a steady way not in a turbine but in nozzles generating thrust. It is the simplest realization of the hybrid wave engine idea. In the next paragraphs, two main hybrid wave engine components (wave gas generator and special gas turbine) will be described.

\section{Wave disk as a gas generator}

In a recent paper, a non-conventional technical realization of the wave machine has been considered. Instead of axial alignment of the compressiondecompression cell axis, the generally radial alignment is proposed. Physi- 
cally, the main difference becomes evident in presence of the centrifugal and Coriollis forces actively engaged in the unsteady compression-decompression process.

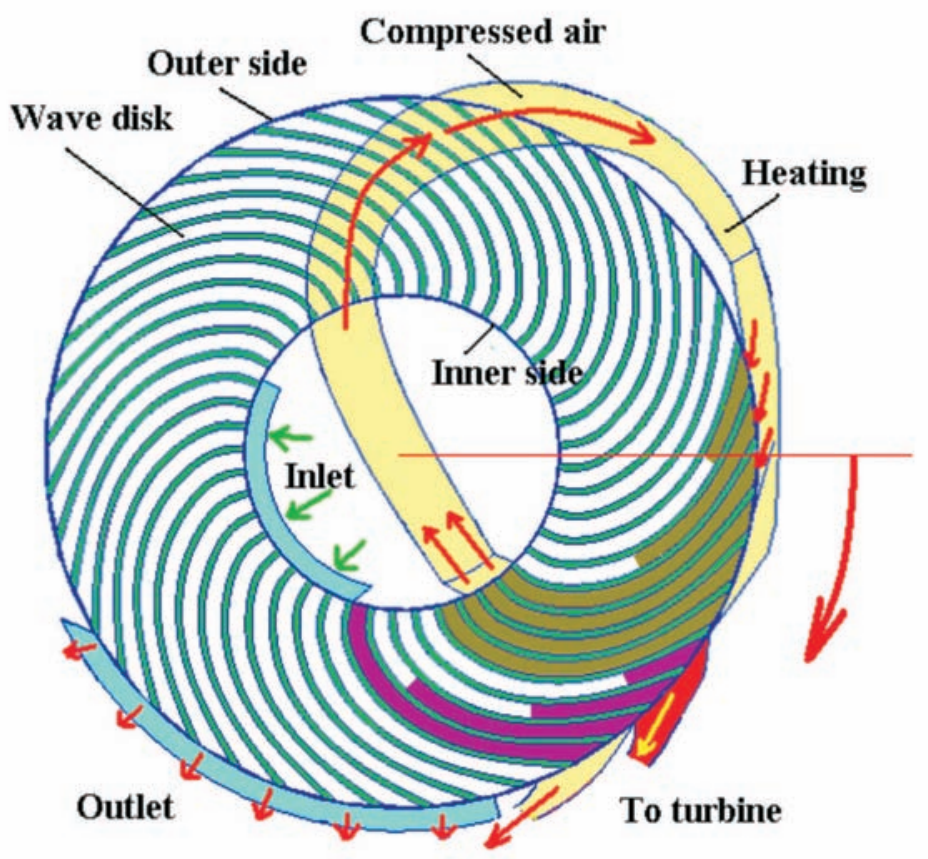

Fig. 8. Schematic position of the main components of the wave gas generator (for simplicity only a single set of ports and passages is shown)

Schematic flow arrangement is presented in Fig.8.

Fig. 8 schematically shows position of the wave disk gas generator basic components. It contains the wave gas generator elements schematically depicted in Fig. 5 and in Fig. 6, but now they are realised in a radial configuration. The set of compression-decompression chambers (cells) in the form of spiral, radially distributed channels forms a rotating element of the gas generator - the wave disk. Fresh air is delivered on the inner side of the disk. Compressed air is collected by two ducts transporting it into the combustion chamber. Heated air is returning to the wave disk through the hot gas ports and gas pockets located at the outer side of the wave disk. One part of the hot gas at high pressure from the wave disk gas generator is directed to a turbine. The other part is exhausted to the environment. The arrows in Fig. 6 show the direction of the flows in the different passages of the device.

For symmetry of thermal stresses, typically a double set of ports is applied. Full model of the flow field is presented in Fig. 9. 


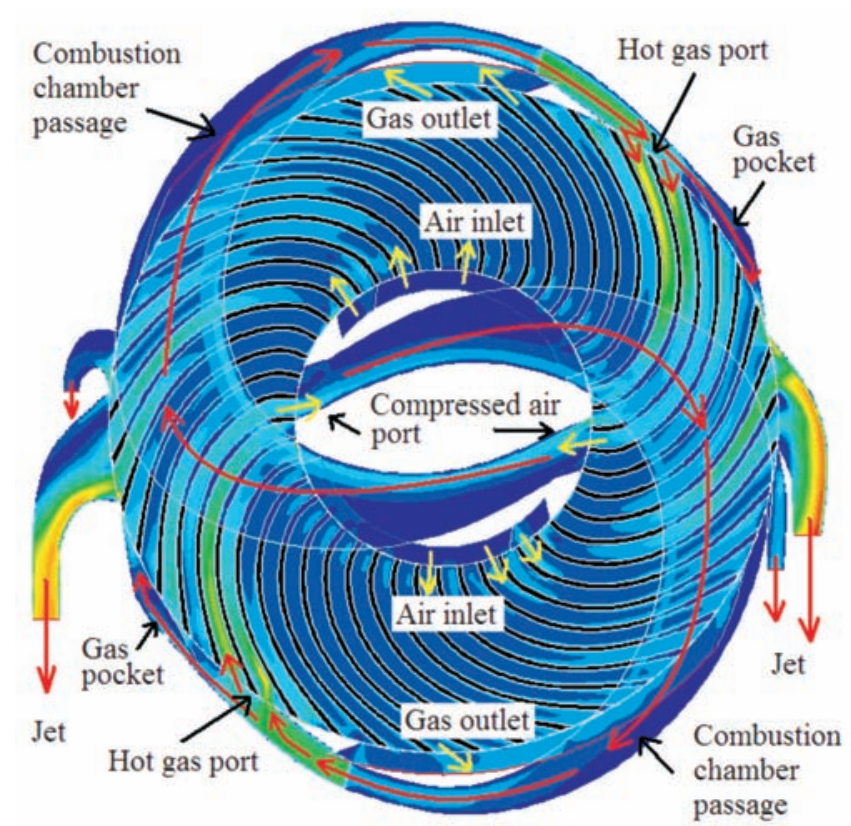

Fig. 9. Full flow field scheme in the possible wave jet engine configuration

\section{Numerical model}

Due to the geometry intended for the use in MEMS technology, which prefers flat parts with shallow channels combined into layers connected by passages (see Fig.7), the two dimensional model of the flow was chosen. First layer contains a disk with compression-decompression channels and a stationary case with a set of ports. The combustion or heat exchanger chamber area forms the second layer. Both layers are connected by passages.

In Fig. 10, the analyzed flow field area is presented. For simulation, flow field was logically divided into two parts, but in another way. Two independent areas exist. One is rotating. It takes over all compression-decompression channels and half width area of the slit between rotor and stator. The second is stationary. It comprises all housing ports and passages. The model is two-dimensional. Some parts of stationary part form a loop and graphically overlap other parts. It is only the graphical effect. All components are topologically independent and are connected only at specific edges.

Wave engine is intended to free aspirate air, then compress and heat it, and eventually expand it to the ambient pressure. Due to that, the pressure inlet and pressure outlet boundary condition are applied at inlets and outlets. Such a type of boundary condition is automatically switched from inlet to outlet, depending on the temporary local flow conditions (reversed flows). 


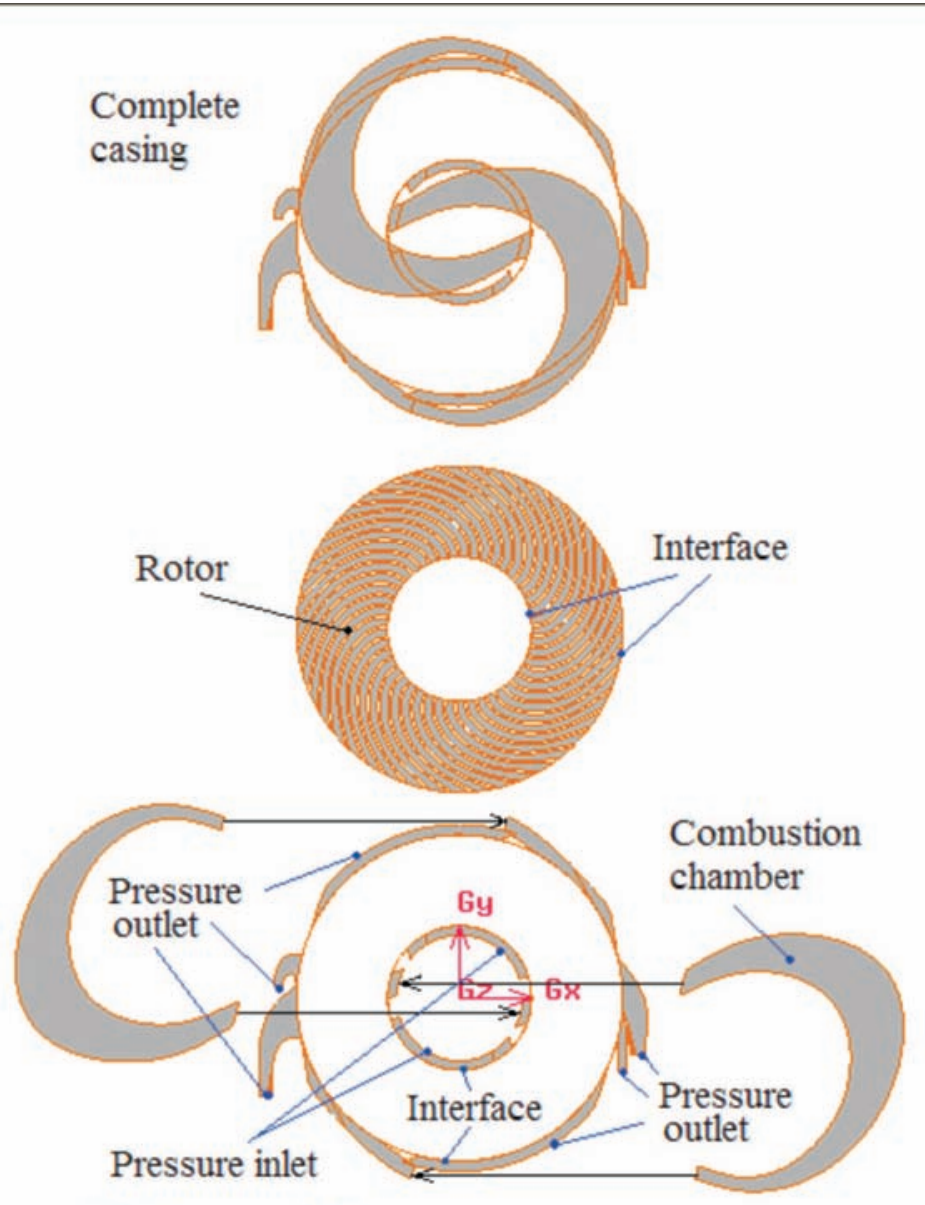

Casing extended

Fig. 10. Scheme of the flow field areas and applied boundary conditions

Stationary and moving grids are interchanging flow parameters at contact edge by the interface boundary conditions.

The expected temperature can vary between $260 \mathrm{~K}$ to $1800 \mathrm{~K}$ and the pressure fluctuates between $90000 \mathrm{~Pa}$ to $400000 \mathrm{~Pa}$. Because of such a wide range of basic thermodynamic parameter change, the compressible fluid model is used in simulations. Due to the unsteadiness of the flow, the Spalart - Allmaras turbulence model is used in viscous flow modeling.

Compressed air is delivered to the chamber (combustion or heat exchanger) where it is heated. Heat can be generated by the chemical process taking place in the passing air when the fuel is injected, or can be delivered from an external source (sun energy). For the simulation of wave engine operation, important is the final effect - change of the air temperature and density. 
Because of that, a simplified heater model was applied. Locally the radiator model was used with known source temperature and known heat transfer coefficient. Under such assumptions, heat stream passed to the compressed air is proportional to an air mass flow rate and the difference between the air temperature on the radiator inlet and radiator temperature.

\section{Results of simulations}

Figures 11-16 show the calculated transient values of some flow parameters recorded at the inner and outer sides of the wave disk. The origin and direction of the nondimensional position variables are indicated by red arrows in Fig. 8.

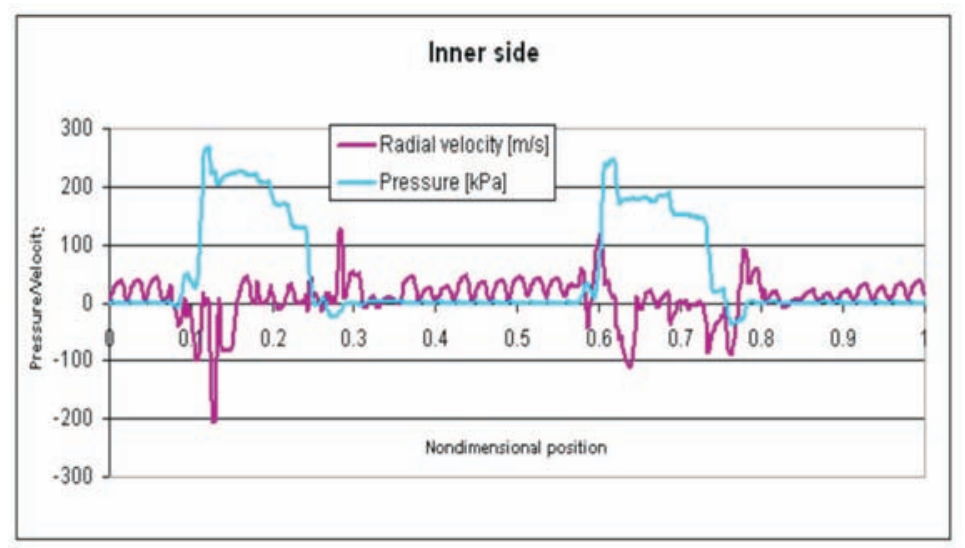

Fig. 11. Comparison of gauge pressure and radial velocity along the inner side of the wave disk

In Fig. 11, variation of the gauge pressure and radial velocity component along the inner side of the disk is presented. It is done for easier interpretation of the correlation between the pressure and velocity from the numerical simulation and the ideal values shown in Fig. 6. The parts of fresh air suction can be easily found in the Fig. 11. Positive velocity represents the inflow to the disk's cells. Negative velocities show the outflow of the compressed air to the combustion chamber.

In Fig. 12, similar data are shown for the outer disk side. The velocities are higher due to the lower density resulting from the lower pressure and higher air temperatures.

Taking into account the data from the numerical simulation of the device operation, it is possible to calculate the compression efficiency. This efficiency is defined as a quotient of the isentropic temperature increase calculated in the assumed compression process, and the simulated temperature increase resulting in the compression. In the flow model used for simulation, physical 


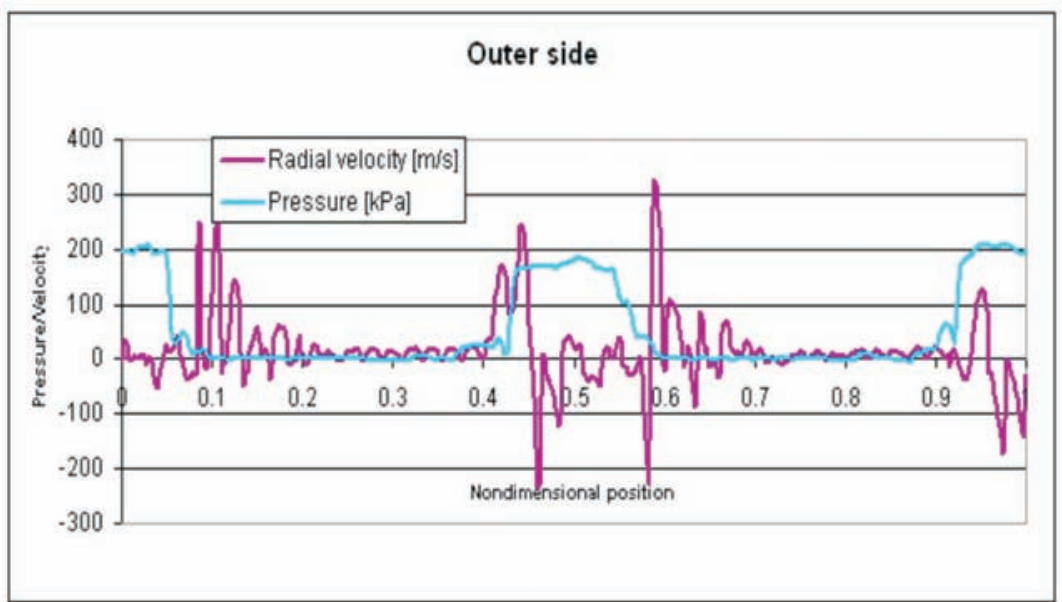

Fig. 12. Comparison of gauge pressure and radial velocity along the outer side of the wave disk

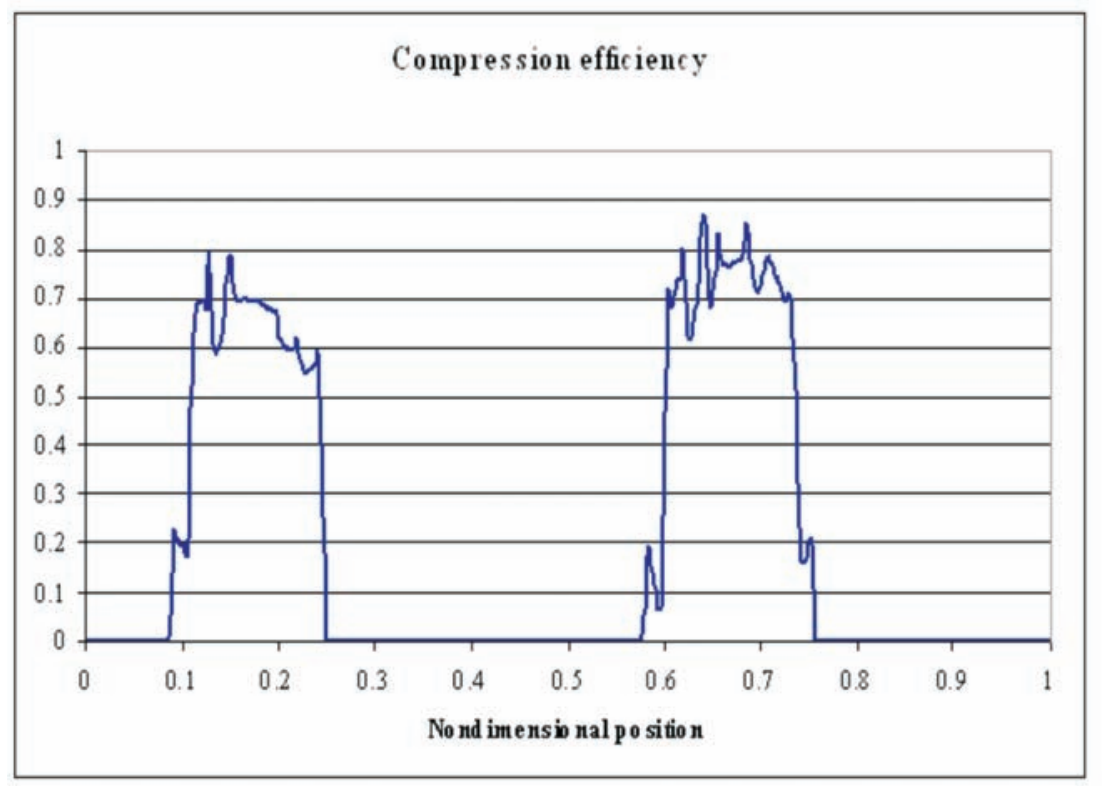

Fig. 13. Calculated unsteady compression efficiency

effects such as gas leakage through the gap between the steady and rotating device parts and the friction losses are taken into account. The resulting mean compression efficiency is on the level of 0.7 .

Fig. 14 presents the transient pressure distribution along the inner and outer sides of the wave disk. The peaks of the pressure on the inner side correspond to the reflected compression waves, whereas the plateu represent 


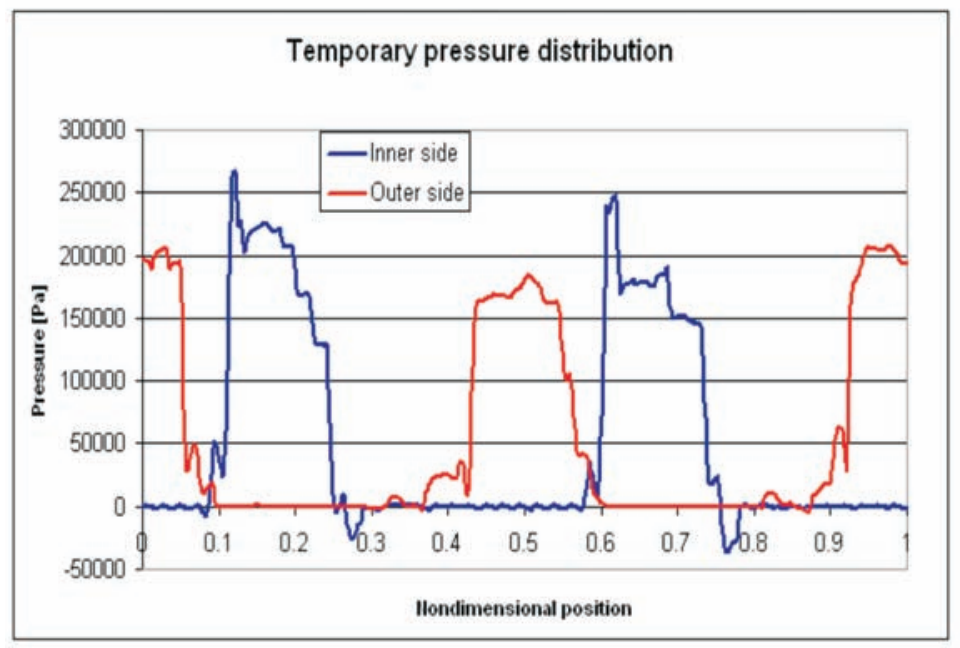

Fig. 14. Distribution of the transient pressure around the inner and outer side of the wave disk

the static pressure at the compressed air ports and the pressure drop due to the expansion waves generated at the outer side of the disk, respectively.

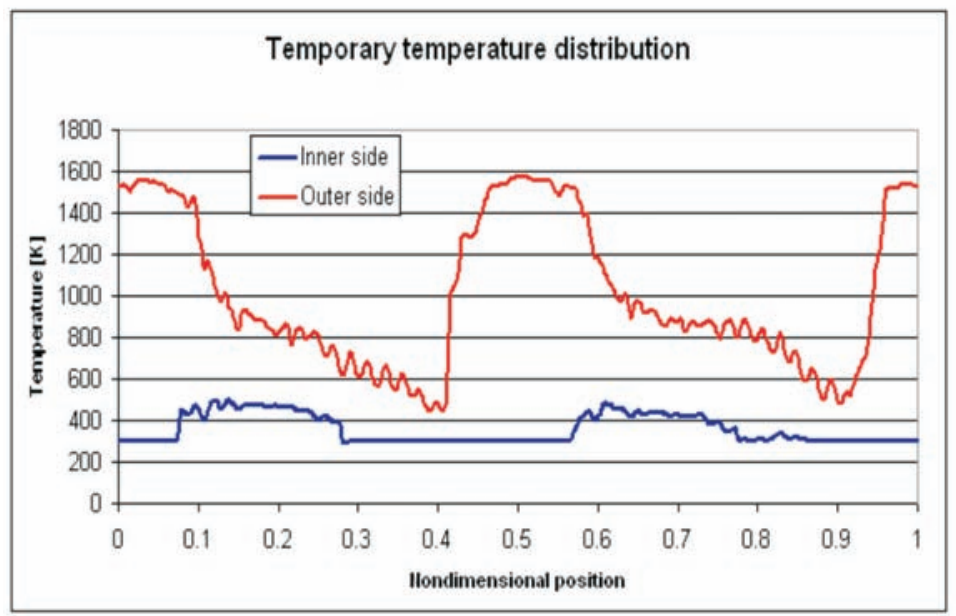

Fig. 15. Transient temperature distribution along the inner and outer side of the wave disk

Fig. 15 shows the variation of the air temperature on the inner and outer side of the disk. Low temperature values inside correspond to the fresh air suction processes. The temperature rise is caused by the compression process. Outside, the progress of the scavenging process is indicated by the continuous drop of the temperature of the hot air flowing out of the disk.

Compression ratio realized in the wave disk gas generator can reach values over 4.0, as seen in Fig. 16. 


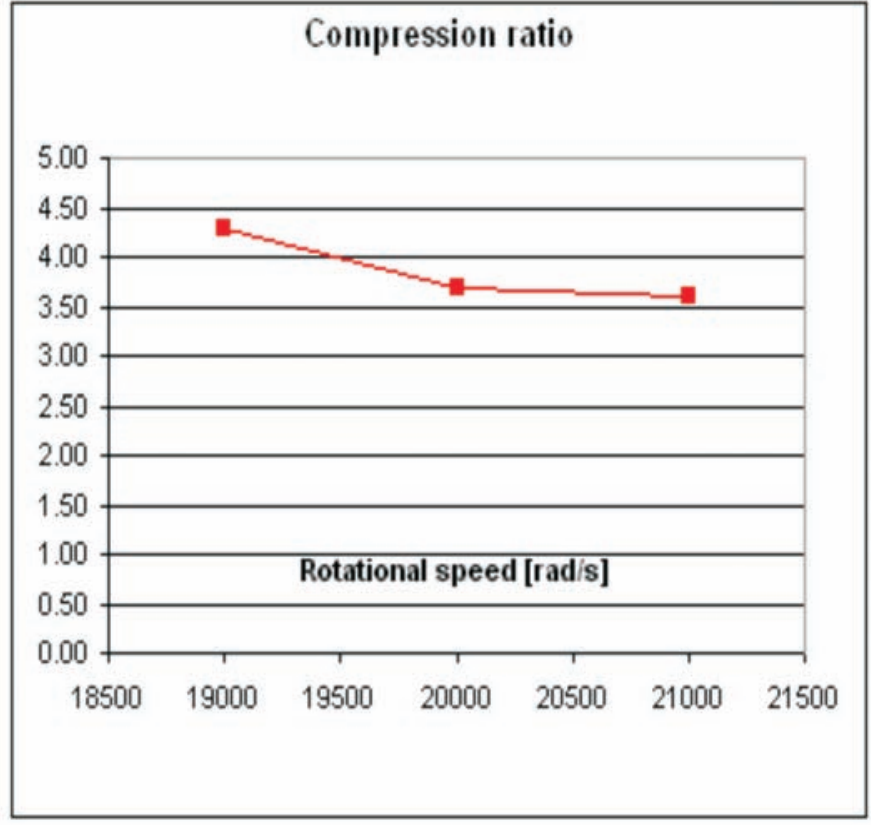

Fig. 16. Variation of the compression ratio due to the disk rotational speed

\section{Multi-stage serial radial turbine}

For simplicity of the wave engine construction, an idea of the special turbine using the same bearing system as the wave gas generator and directly connected with the wave disk has been considered. Due to the flat disk geometry, a classic turbine cannot be used. The multi-stage radial turbine concept was thus considered.

A multi-stage radial type of turbine was analyzed by Frechette $[4,11]$ for application of the Rankine process model. Unfortunately, in our case, the flow rate of exhaust gases from the hot gas source (gas generator) was inapplicable for such a parallel turbine-configuration (see Fig. 17, left). Hence, a serial variant of a radial turbine is proposed in this paper (see Fig. 17, right).

A special tip turbine suitable in the case of a gas generator delivering a small amount of hot gases under the high pressure is known as a torque generator for the turbo fans [9]. This idea is adapted here to the hybrid wave engine.

Fig. 18 shows the flow scheme inside the two-step serial radial turbine. High-pressure hot gases from the gas generator are directed to the gas turbine. After partial expansion, the exhaust gases are conducted again to the turbine blades. The same set of blades is used as high-pressure and low-pressure stages of decompression. Only a single row of turbine blades is used, but the 


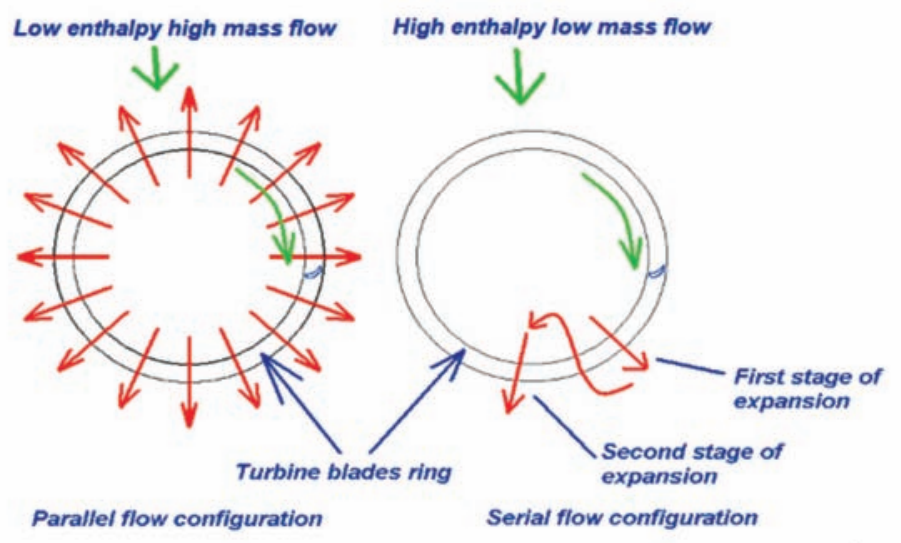

Fig. 17. Parallel and serial flow configurations of a radial turbine

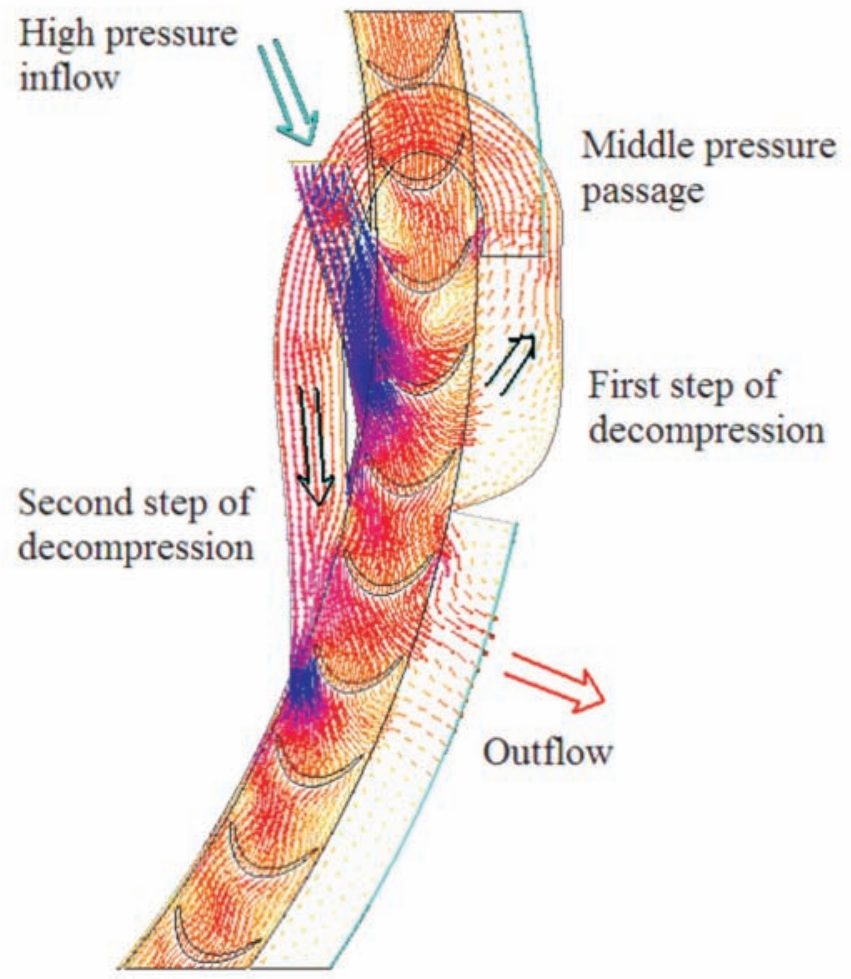

Fig. 18. Flow scheme in two-step serial radial turbine

expanded gas is passing through this row of blades twice. The functionality of a similar configuration for the tip turbine was experimentally confirmed in [9]. 
Fig. 19 shows the transient pressure, temperature, velocity, and velocity vectors inside the two-step serial radial turbine.

In the proposed turbine configuration, each turbine blade is affected by the very hot exhaust gases only during the short time when the blade is passing near the high-pressure and high-temperature inlet nozzle. Later, the blade is cooled by the expanded gases. The gas inlet temperature can thus be higher than in a conventional gas turbine.

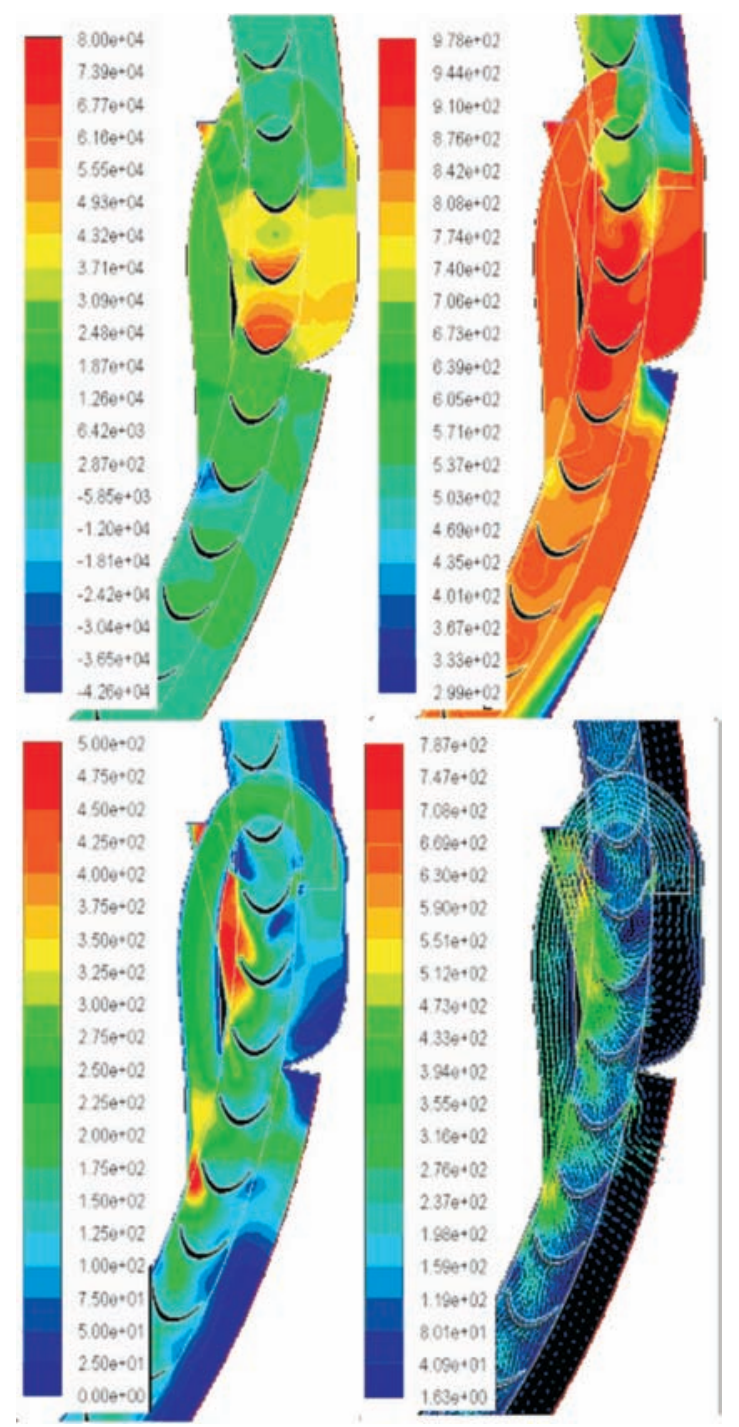

Fig. 19. Pressure and temperature (top row), velocity and velocity vectors (bottom row) in two-step serial radial turbine 


\section{Numerical simulation of the hybrid wave engine operation}

By addition of the multistage radial turbine to the wave disk gas generator, an example of hybrid engine was realized. A hybrid wave engine has two main components, namely a gas generator utilizing the unsteady flow phenomena and a torque generator based on the steady-state flow principle.

To simplify the hybrid wave engine construction, the radial type of turbine located on the wave disk is proposed (see Fig. 20). The hybrid engine model analyzed contains all flow loops necessary to fully control the flow parameters.

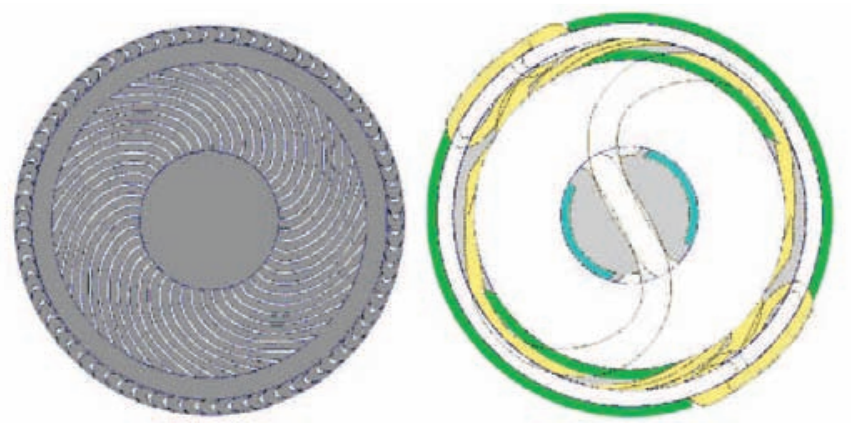

Fig. 20. Hybrid wave rotor and casing

The compressed air ports are connected through a simulated area of heat addition inside the combustion chamber with hot gas high-pressure ports generating the compression process. The pressure inside the simulated combustion chamber is variable in time, and is developing as a function of the inflow and outflow conditions. The heat stream transferred to the compressed air depends on the actual air mass flow rate and the difference between assumed constant temperature of the heater and the local air temperature passing the heater.

Fig. 21 shows the schematic diagram of the internal flows inside the hybrid wave engine (inside the gas generator and radial serial turbine). For simplicity, only a single set of ports is shown. Details and the legend for Fig. 21 are included in Fig. 22.

In a hybrid engine, two contradicting trends must be combined, and a compromise between their effects has to be found. On the one hand, for the operation of the gas generator working in unsteady mode, low rotational speeds are required. On the other hand, torque generation by the steady flow process is most efficient at high rotational speeds. For simplicity, the gas generator and the torque generator are located on the same disk (see Fig. 20) so that the gas generator channels and the turbine blades rotate at the same 


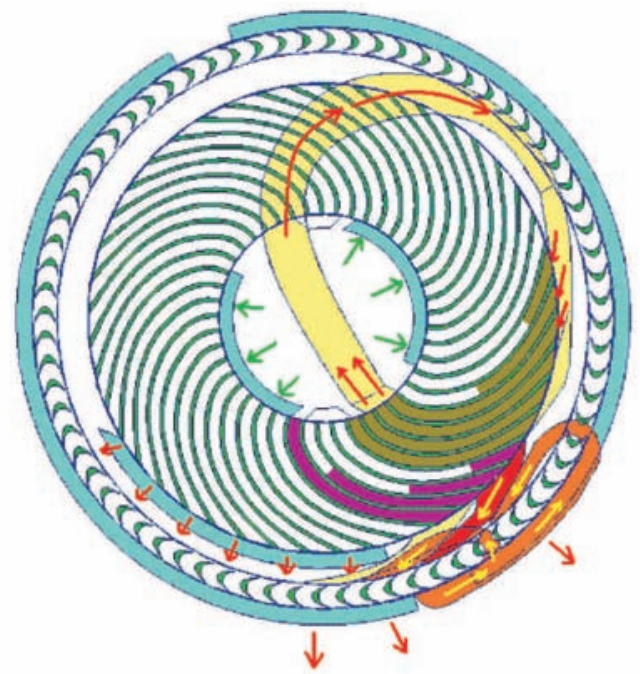

Fig. 21. Scheme of the internal flows inside the wave engine (single port set included for simplicity)

speed. The set of turbine blades is located on the greater radius than the wave gas generator, which slightly increases the linear speed of the blades.

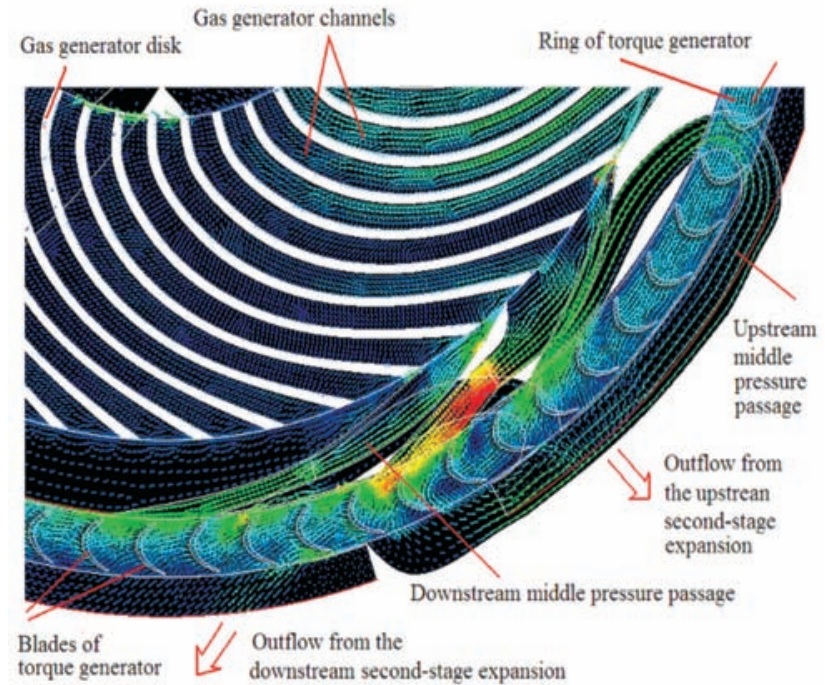

Fig. 22. Mechanically connected gas generator disk and ring of torque generator

Fig. 22 presents a view of the geometrical relations between the wave disk and the turbine blade row. 


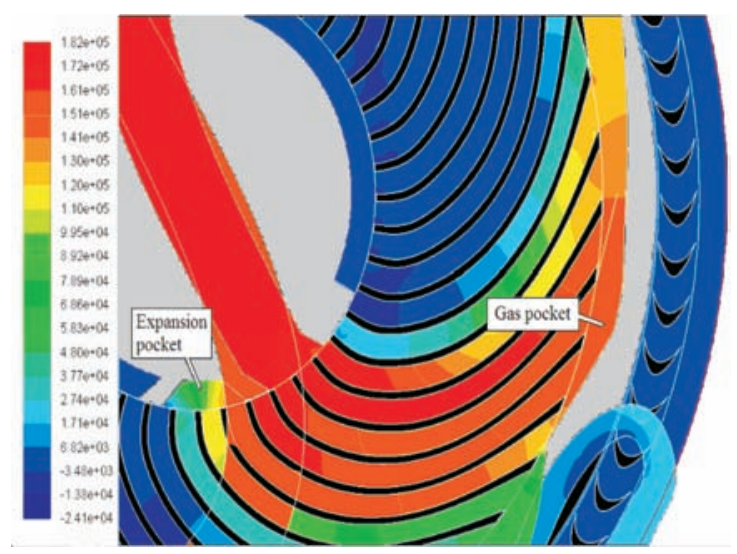

Fig. 23. Pressure distribution - configuration with open gas pocket and closed expansion pocket

As shown in Fig. 23, a gas pocket is used to increase the outflow pressure from the gas generator.

The geometries of the gas generator unit and the turbine unit have been modified repeatedly during the investigation in order to reach the optimal configuration.

Generally, cells of the gas generator have an arch shape and a constant cross-section.

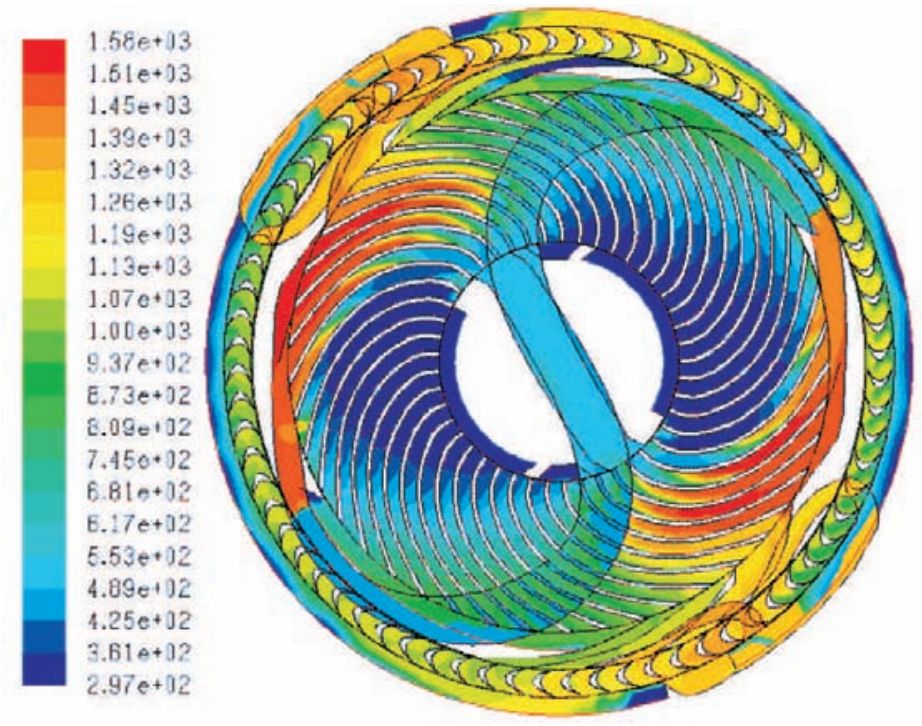

Fig. 24. Temperature distribution inside the channels and passages of the hybrid wave engine

Fig. 24 shows the temperature distribution inside the flow areas of the hybrid wave engine. One can observe the hot-cold gas interface motion in 
direction of rotor axis, outflow to the turbine part and scavenging area. The highest temperature exists in the high-pressure hot exhaust gas ports, gas pockets and temporarily inside the disk cells. The transient steps and final depth of the hot air penetration range inside the compression-decompression channels are evident. Also the progress of the scavenging process is clearly visible. While the disk cells are cooled by the fresh cold air, the ports are the most critical parts of the device due to their constant contact with hightemperature gas.

Fig. 25 depicts the pressure distribution inside the hybrid wave engine. Hence, the formation process of the compression wave (shock wave) is evident.
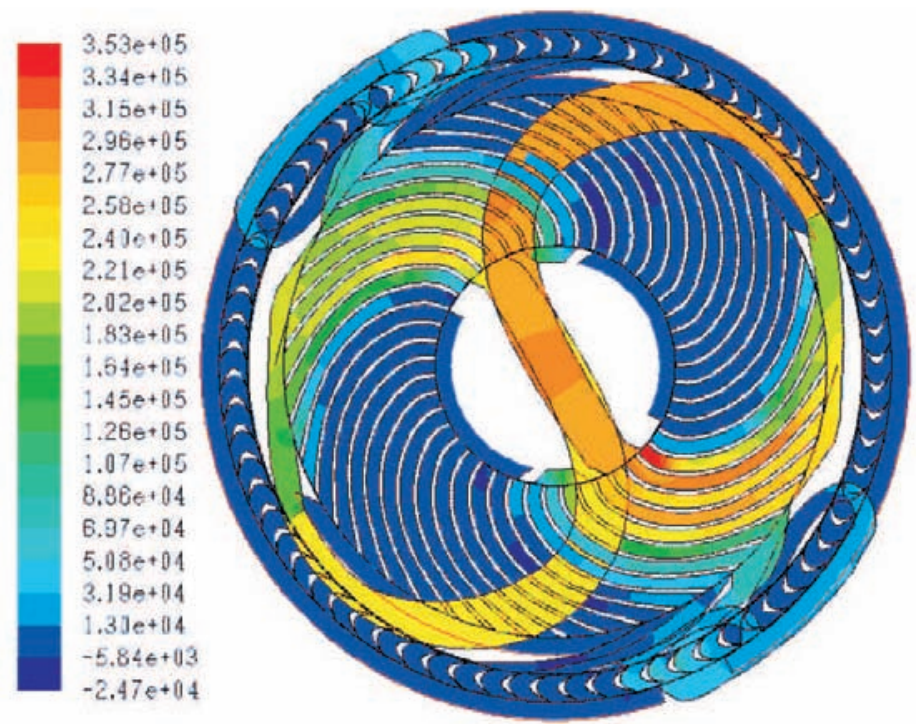

Fig. 25. Pressure distributions inside hybrid wave rotor flow areas

Fig. 26 shows the magnitudes of the velocity inside the disk channels and case passages. Relatively high velocities correspond to the steady decompression process in high pressure passages supporting the first stage of the turbine. In numerical simulations of the device in operation, two main scale dimensions were considered, namely the centimeter scale with a wave disk diameter equal to $120 \mathrm{~mm}$ and a millimeter-scale with a wave disk dimension of $30 \mathrm{~mm}$. Additionally, a device with a disk diameter of $14 \mathrm{~mm}$ was considered.

The larger scale was considered in the course of the development of a hybrid engine demonstrator tested by commonly used laboratory equipment. 

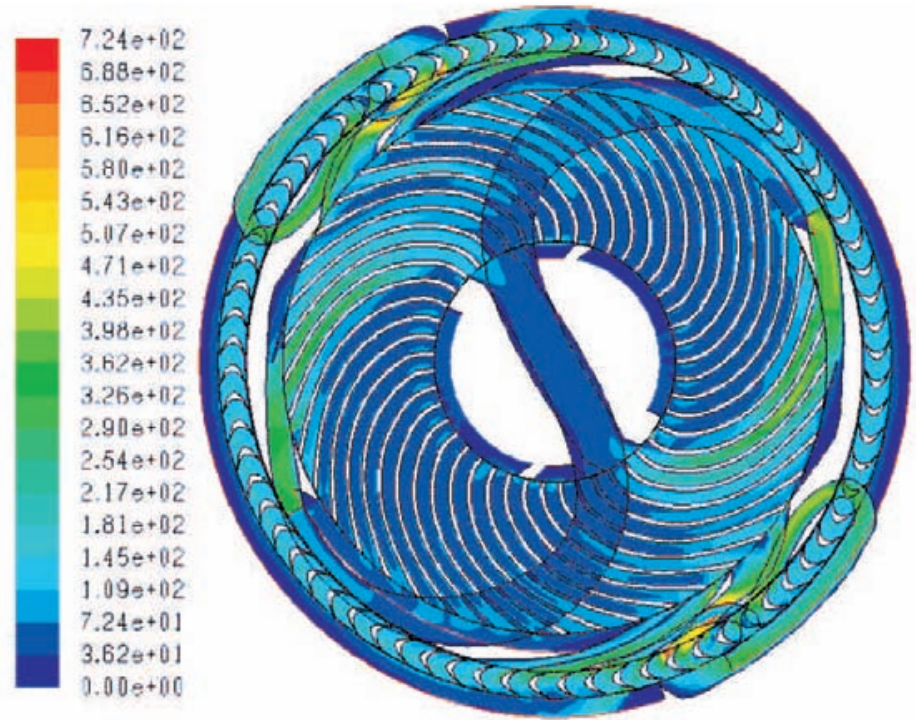

Fig. 26. Velocity magnitude inside flow areas of the hybrid wave engine

The smaller scale model is considered as a final solution. In Table 1, the basic parameters of the hybrid engine model considered are listed.

Table 1.

Basic parameters of hybrid engine models considered

\begin{tabular}{|c|c|c|c|c|}
\hline $\begin{array}{c}\text { Rotor diameter } \\
{[\mathrm{mm}]}\end{array}$ & $\begin{array}{c}\text { Rotational speed } \\
{[\mathrm{rpm}]}\end{array}$ & $\begin{array}{c}\text { Tip linear } \\
\text { speed } \\
{[\mathrm{m} / \mathrm{s}]}\end{array}$ & $\begin{array}{c}\text { Power } \\
{[\mathrm{W}]}\end{array}$ & $\begin{array}{c}\text { Rotor cell } \\
\text { height } \\
{[\mathrm{mm}]}\end{array}$ \\
\hline 142 & 19100 & 140 & 1100 & 4 \\
\hline 33 & 76400 & 140 & 110 & 2 \\
\hline 14 & 172000 & 130 & 20 & 1 \\
\hline
\end{tabular}

For all scales, the maximum total efficiency of the hybrid engine considered reached $10 \%$. Mainly due to the channel curvature elongating the cell length, the rotational speed of the rotor was reduced twice after the first attempt [20]. In recent investigations only single-step compression schemes have been applied.

In the present engine configuration, depending on the construction details, $65 \%$ to $80 \%$ of the air stream entering the engine is passing through the combustion chamber and is heated to a temperature of over $1200 \mathrm{~K}$. Hence, $20 \%$ to $35 \%$ of the stream is used as a cooling air. From the air stream passing through the combustion chamber, $75 \%$ to $90 \%$ is directed to the turbine and $10 \%$ to $25 \%$ is mixed with the cooling air and extracted in 


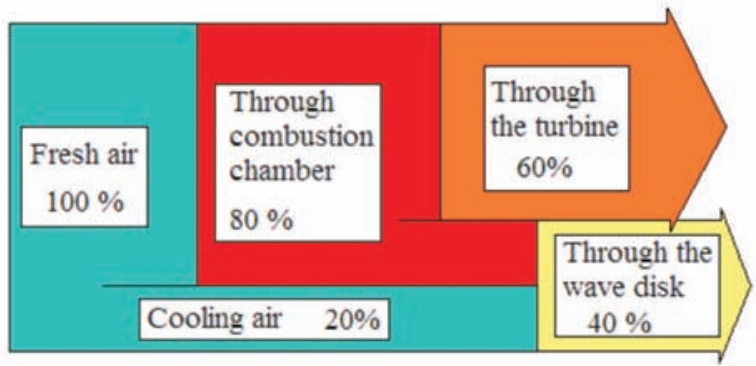

Streams distribution

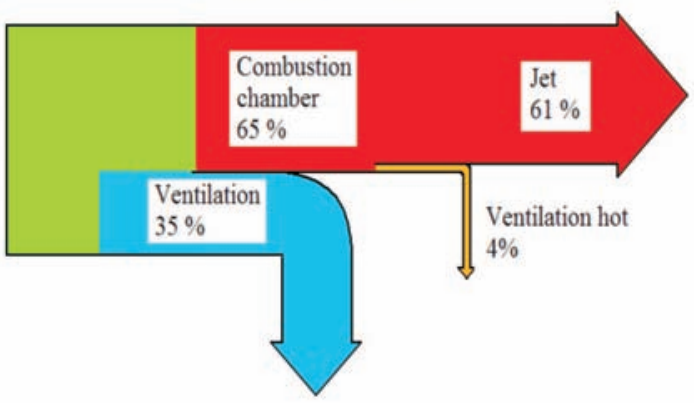

Fig. 27. Hybrid engine air stream distribution (version A and B)

an unsteady process stimulated by the centrifugal forces. Generally, $60 \%$ to $70 \%$ of the air aspired is expanded in the steady way and 30 to $40 \%$ in an unsteady way.

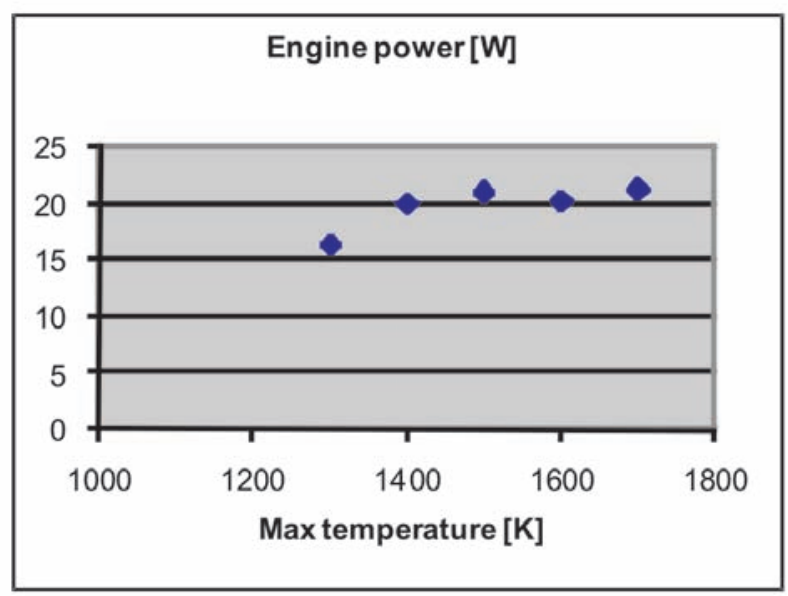

Fig. 28. Variation of the engine power versus gas temperature 

30 .

Basic parameters of the smallest engine version are presented in Figs. 28-

The range of the operational gas temperatures of the hybrid engine was defined. On the one hand, the highest temperature was limited by the material properties, and on the other hand, the minimum temperature was limited by a stable engine operation. It was found that the engine can work if the hot air temperature after the combustion chamber is higher than $1200 \mathrm{~K}$.

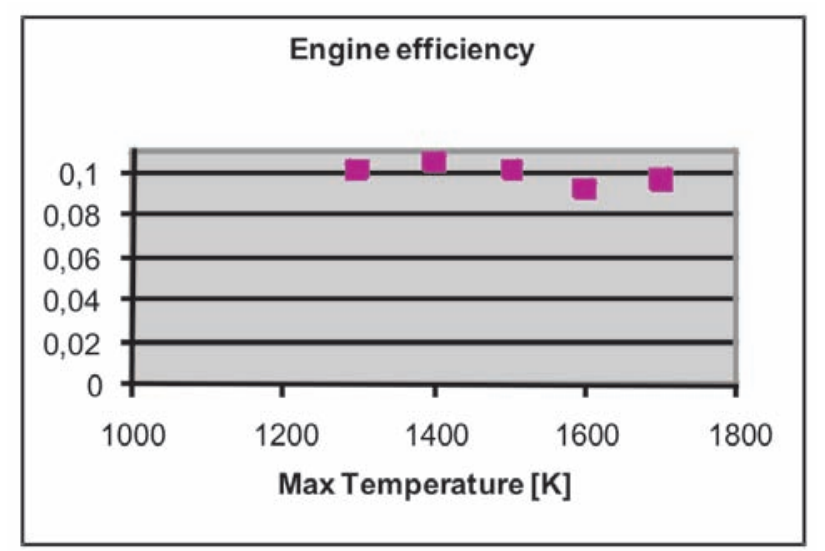

Fig. 29. Variation of the engine efficiency versus gas temperature

At the operational range of temperatures, engine efficiency is defined as the ratio of the power generated by the wave disk and turbine to the heat delivered to the air. It oscillated near the 10\% value, as presented in Fig. 30.

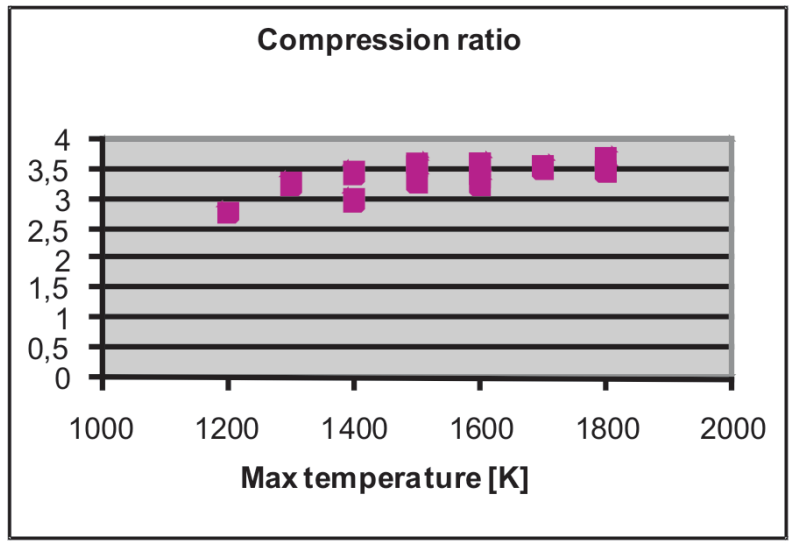

Fig. 30. Variation of the engine compression ratio versus gas temperature

The compression ratio is defined as the compressed air pressure to ambient pressure. It varies with the hot gas temperature, reaching the value of 3.5 
(see Fig. 30). For temperatures lower than $1200 \mathrm{~K}$, the compression process disintegrates and the compressed air pressure drops down to the level of the ambient pressure. The engine can not operate below the temperature of $1200 \mathrm{~K}$ in combustion chamber.

\section{Conclusions}

The calculations of a two-dimensional hybrid wave engine model performed using Fluent code confirmed the expectations. Using only a single moving part containing a gas generator radial channel set and a single row of radial turbine blades, it was possible to show the generation of net power at a stable operation of the gas generator unit. Without even optimizing the elements of the torque generator (blade shape, dimension of nozzles, nozzle angles), the generated torque shows reasonable values. The efficiency, defined as the ratio of the generated mechanical power to the delivered heat power reaches $10 \%$. It has thus been shown that a wave machine can effectively be used as an autonomous gas generator.

The gas generator unit, which is self-driven, can be mechanically separated from the torque generator unit. In such a configuration, a typical radial or axial turbine can be used as a torque generator device. Since the simplicity of a solution was the most important device feature in this project, a single rotating disk construction was analyzed.

Taking into account the results achieved in this investigation, a design of the hybrid engine demonstrator for the power range of $1000 \mathrm{~W}$ seems to be possible. The diameter of the disk of such a demonstrator should be about $15 \mathrm{~cm}$, with a thickness of about $3 \mathrm{~cm}$. In such a scale, a typical measuring technique can be used for steady and unsteady measurements of pressure, gas velocities and temperatures. It would be the intermediate step before designing a smaller, $3 \mathrm{~cm}$ diameter model. A hybrid engine made with MEMS technology with a diameter of $15 \mathrm{~mm}$ and a thickness of $3 \mathrm{~mm}$ can generate $20 \mathrm{~W}$ of mechanical power with an efficiency of about $10 \%$.

Manuscript received by Editorial Board, December 14, 2009; final version, February 03, 2010.

\section{REFERENCES}

[1] Akbari, P.: "Performance Prediction and Preliminary Design of Wave Rotors Enhancing Gas Turbine Cycles," Ph.D. Dissertation, Mechanical Engineering, Michigan State University, East Lansing, MI, 2004.

[2] Epstein A.H.: "Millimeter-scale, MEMS gas turbine engines," GT-2003-38866,Proc of ASME Turbo Expo 2003, June 16-19, 2003, Atlanta, GA, 2003. 
[3] Frąckowiak M., Iancu F., Potrzebowski A., Akbari P., Müller N., Piechna J.: "Numerical simulation of unsteady flow processes in wave rotors," IMECE2004-60973, 2004.

[4] Frechette L.G.: "Development of a Microfabricated Silicon Motor-Driven Compression System,” Ph.D. Dissertation, Mass. Inst. Of Technol., Camridge, MA, 2000.

[5] Hoerler H.U.: „Abschätzung der Verluste in Instationär-Gasdynamischen Kanal-TrommelDruckauschern.“ Ph.D. thesis, No 4402, ETH Zurich, Switzerland, 1969.

[6] Iancu, F.: "Integration of a Wave Rotor to an Ultra-Micro Gas Turbine (UmGT)," Ph.D. Diss., Mechanical Engineering, Michigan State University, East Lansing, MI, 2005.

[7] Iancu F., Piechna J., Dempsey E., Müller N.: "Ultra-Micro Wave Rotor Investigations," Technical Digest PowerMEMS 2005, The Fifth International Workshop on Micro and Nanotechnology for Power Generation and Energy Conversion Applications, Nov. 28-30, 2005 Tokyo, Japan, pp. 93-96.

[8] Iancu F., Piechna J., Dempsey E., Müller N.: "The Ultra-micro Wave Rotor Research at Michigan State University," The $2^{\text {nd }}$ International Symposium on Innovative Aerial/Space Flyer Systems (Dec. 2-3, 2005 The University of Tokio) PL-12, pp. 65-70.

[9] Iwase S., Saito Y., Matsuda Y.: "Cluster Fan VTOL”, International Symposium on Innovative Aerial/Space Flyer Systems (Dec. 10-11, 2004, The University of Tokyo) G-6, pp. 73-80.

[10] Kentfield J.A.C.: " Nonsteady, One-Dimensional, Internal, Compressible Flows - Theory and Applications", Oxford University Press, New York, 1993.

[11] Lee C., Frechette L.G.: 2005, "Experimental Development of the Rotating Subsystem for a Micro Rankine Power System“, Technical Digest Power MEMS 2005, The Fifth International Workshop on Micro and Nanotechnology for Power Generation and Energy Conversion Applications”, Nov. 28-30, Takeda Hall, The University of Tokyo, Tokyo, pp. 37-40.

[12] Mayer A.: "The Free Running Comprex - A New Concept for Pressure Wave Supercharger," SAE Document PC 55, 1988

[13] Nagashima T., Okamoto K.: "Experimental investigation of the wave discs." Personal communication, 2005.

[14] Pearson R. D.: "A Gas Wave-Turbine Engine Which Developed 35 HP and Performed Over a 6:1 Speed Range", Proc. ONR/NAVAIR Wave Rotor Research and Technology Workshop, Report NPS-67-85-008, pp. 403-49, Naval Postgraduate School, Monterey, CA., 1985.

[15] Piechna J., Akbari P., Iancu F., and Müller N.: "Radial-flow wave rotor concepts, unconventional designs and applications," IMECE2004-59022, 2004.

[16] Piechna J.: "Wave Machines, Models and Numerical Simulation", Oficyna Wydawnicza Politechniki Warszawskiej, Warszawa, 2005.

[17] Piechna J.: "Feasibility Study of the Wave Disk Micro-Engine Operation," Technical Digest PowerMEMS 2005, The Fifth International Workshop on Micro and Nanotechnology for Power Generation and Energy Conversion Application, Nov. 28-30,2005, The University of Tokyo, Tokyo, Japan pp. 69-72.

[18] Piechna J.: "The micro jet wave engine idea," The $2^{\text {nd }}$ International Symposium on Innovative Aerial/Space Flyer Systems (Dec. 2-3, 2005 The University of Tokio) PL-12, pp. 71-78.

[19] Piechna J.: "Numerical Study of the Wave Disc Micro-Engine Operation", The Archive of Mechanical Engineering, vol. XLV, Nr 4 pp. 305-323, 2006.

[20] Piechna J.: "Feasibility study of the wave disk micro-engine operation", Journal of Micromechanics and Microengineering, 16 (2006), 270-281.

[21] Piechna J., Dyntar D.: " Two-Dimensional Numerical Analysis of the Wave Jet Micro-engine Operation”, Power MEMS 2007, 28-29 November 2007, Freiburg, Germany.

[22] Piechna J., and Dyntar D.: Numerical investigation of the Wave Disk Micro-Engine features" (to be published).

[23] Ribaud Y., Dessornes O., Guidez J., Courvoisier T., Dumand C., Kozanecki Z., Helin P., Le Moal P., Minotti P.: "The experience gained on the ultra microturbine: from energetics to component bricks studies," Technical Digest PowerMEMS 2005, The Fifth Internation- 
al Workshop on Micro and Nanotechnology for Power Generation and Energy Conversion Application, Nov. 28-30, 2005, The University of Tokyo, Tokyo, Japan pp. 21-24.

[24] Shapiro A.H.: "The Dynamics and Thermodynamics of Compressible Fluid Flow," John Wiley and Sons, 1958.

[25] Schneider B., Bruderer M., Dyntar D., Zwyssig C., Diener M., Boulouchos K., Abhari R.S., Guzzella L., Kolar J.W.: "Ultra-High-Energy-Density Converter for Portable Power,“ Technical Digest PowerMEMS 2005, The Fifth International Workshop on Micro and Nanotechnology for Power Generation and Energy Conversion Application, Nov. 28-30, 2005, The University of Tokyo, Tokyo, Japan pp. 81- 4.

[26] Weber H. E.: "Shock Wave Engine Design“, John Wiley \& Sons, New York, 1995.

\section{Koncepcja hybrydowego silnika falowego i numeryczna symulacja jego pracy}

\section{Streszczenie}

Badania prowadzone nad mikrosilnikami przepływowymi ukazały ich główna wadę jaką jest niska sprawność stacjonarnego procesu sprężania wynikająca z ich małych wymiarów. Jako rozwiązanie tego problemu proponuje się zastosowanie nieustalonych procesów sprężania. Dalsze badania wykazały ich przydatność w procesie sprężania lecz nieprzydatność do wytwarzania momentu napędowego. Dlatego też opracowano nową koncepcję falowego mikro silnika łączącego korzystne cechy stacjonarnych i niestacjonarnych procesów przepływu.

W niniejszej pracy przedstawiono nową ideę hybrydowego silnika falowego i numeryczne symulacje jego działania. W proponowanym hybrydowym silniku falowym zastosowano elementy konstrukcyjne wywołujące nieustalone sprężanie a stacjonarne rozprężanie, mieszanego typu (nieustalone i ustalone) opróżnianie komór sprężająco-rozprężających wspomagane działaniem sił odśrodkowych. Ponieważ technologia stosowana w przypadku urządzeń typu MEMS preferuje a czasem wręcz wymaga płaskiej geometrii, zastosowano układ sprężający typu promieniowego. Zbudowany został numeryczny, dwu-wymiarowy model silnika zawierający wszystkie typowo modelowane jego elementy oraz uproszczony model komory spalania zamykający obieg sprężonego powietrza pomiędzy wylotem z układu sprężającego a wlotem do układu rozprężającego. Do wytwarzania momentu obrotowego wykorzystano promieniową turbinę specjalnego typu z szeregowym układem stopni rozprężania. 